\title{
Hannah Arendt: el judío de excepción y su fracaso en el proceso de integración a la sociedad alemana en la modernidad ${ }^{1}$
}

Hannah Arendt: The Jew of Exception and his failure in the process of assimilation to German society in modernity

\author{
Paula Calderón \\ paulacalderonm@gmail.com \\ Universidad de Chile \\ Chile
}

\section{Resumen}

En este trabajo analizaremos, siguiendo los planteamientos realizados por Hannah Arendt, cómo se produjo la asimilación entre la cultura europea moderna con la cultura judía en el contexto que rodea la emancipación de este pueblo en la Alemania del siglo XVIII. Para ello, se seguirán los planteamientos realizados por la pensadora en los textos La Ilustración y la cuestión judía y Los orígenes del totalitarismo. Para llevar a cabo este proceso, reflexionaremos en torno a la hipótesis de lectura que construye la autora bajo dos imágenes ideales, centrándose en dos tipos humanos que para la filósofa alemana expresarán a dos modelos de judíos concretos: el judío culto de excepción y el judío de excepción de la riqueza. Por este motivo, para comprender este período, seguiremos el desarrollo de estas dos figuras arquetípicas, las que contienen una "validez ejemplar" para la filósofa alemana.

Palabras claves: judío culto de excepción - judío de excepción de la riqueza - Herder Lessing - Mendelssohn - asimilación.

\footnotetext{
${ }^{1}$ El presente artículo sintetiza el capítulo 1 de Hannah Arendt y la condición judía: Paria y advenedizo, dos actitudes posibles frente a la judeidad, tesis de la autora para optar al grado de Magister en Filosofía, de la Universidad de Chile.
} 


\begin{abstract}
In this paper, we will analyze Hannah Arendt's approach to the assimilation between the Modern European culture and the Jewish culture in the context of the emancipation of the Jews in eighteenth-century Germany. For this, we will follow the approaches made by the Arendt in the texts The Enlightenment and the Jewish question and The origins of Totalitarianism. To carry out this process, we will reflect on the hypothesis of reading that the author constructs under two ideal images, focusing on two human types that for this German philosopher will express two models of concrete Jews: the Jewish cult of exception and the Jewish Of exception of the wealth. For this reason, to understand this period, we will follow the development of these two archetypal figures, those containing an "exemplary validity" for the German philosopher.
\end{abstract}

Key words: Jewish cult of exception - Jewish exception of wealth - Herder - Lessing Mendelssohn - assimilation.

\title{
1. Judío culto de excepción
}

El historiador Salo W. Baron (1960), en su artículo Nuevos enfoques acerca de la emancipación judía señala que la palabra emancipación en la historia judía, corresponde a la liberación de las minorías judías de las trabas legales que se les habían impuesto, sobre todo en la Europa cristiana, y de su transformación de grupos étnicos tolerados y limitados en sus derechos, para convertirse en ciudadanos de sus respectivos países.

Como plantea el autor, generalmente se ha ubicado el comienzo de la emancipación judía moderna a partir de la legislación emancipatoria de la Revolución francesa, con la proclamación de la Asamblea Nacional de la igualdad de derechos de los judíos desde 1790. A la etapa preemancipatoria se la ha denominado medioevo o mundo tradicional judío, el que duró hasta bastante después de 1492. 
Justamente Hannah Arendt se situará en este contexto, específicamente en la Alemania del siglo XVIII, para explicarnos que tanto los planteamientos efectuados por los pensadores promotores de la emancipación judía como la definición que ellos establecieron de la asimilación de este pueblo, generaron el concepto de judío de excepción, noción que la autora desarrollará en La Ilustración y la cuestión judía y Los orígenes del totalitarismo.

Para comenzar, la filósofa alemana señalará en Los orígenes del totalitarismo, que todos los que defendían la emancipación judía exigían, a su vez, la asimilación de este pueblo, ya sea como condición preliminar de la emancipación o bien como su consecuencia; conceptualizando la asimilación judía como "el acoplamiento y la recepción por parte de una sociedad" de estos individuos (Arendt, 2010a, p.130). Producto de esta definición, como nos dirá la autora, estos pensadores abordaron la inserción judía desde el punto de vista social, presentándola por ello, como si se tratase de un problema de 'formación' o 'educación'. Como plantea Arendt (2010a, p.130):

"La sociedad, enfrentada con la igualdad política, económica y legal de los judios, dejó claro que ninguna de sus clases se hallaba preparada para concederles la igualdad social, y que sólo serían admitidas excepciones del pueblo judío. Los judios que escuchaban el extraño cumplido de que constituían excepciones, que eran judís excepcionales, sabían muy bien que era esta misma ambigüedad -la de ser judios y presumiblemente no como judios- la que les abría las puertas de la sociedad. Si deseaban este género de relación, trataban, por eso, de 'ser y no ser judios"'.

De esta cita se desprende, siguiendo a la pensadora, que esta excepcionalidad ofrecida por la sociedad alemana, puede ser entendida en primer lugar como excluyente: se tratará de la aceptación de unos pocos -ya que sólo serían aceptadas excepciones de este pueblo -, en función de la marginación de los muchos, el grueso de la población judía. De esta manera, podemos observar cómo el judío de excepción no sólo será extraordinario porque tiene 
cualidades determinadas, sino porque se contrapondrá al "judio ordinario". (Arendt, 2010a, p.130)

Así, podemos apreciar, cómo se produce una oposición entre lo ordinario y lo extraordinario. Si definimos la excepcionalidad como algo que se sale de la regla común y se aparta de lo ordinario. Y, justamente, aquello que es ordinario, lo conceptualizamos cómo lo que es común o incluso como lo que puede ser basto, vulgar, de poca estimación o que no tiene grado. Podemos decir entonces cómo se presenta aquí una contraposición entre el judío de excepción, aquel que se sale de toda norma; en antagonismo con el 'judío ordinario', considerado precisamente por la sociedad como el individuo incivil, corriente, general y de poca estimación.

En este sentido, se puede plantear que el carácter excluyente de esta diferenciación, entre lo ordinario y lo extraordinario, supondrá marginalizar de la vida europea al pueblo judío, al ser considerado que está compuesto precisamente por individuos comunes y sin distinción; en virtud del ingreso a la sociedad de unos pocos, aquellos judíos excepcionales. De esta manera, en la idea de excepción está supuesta la exclusión de las masas judías al proceso de asimilación.

Siguiendo el análisis de la pensadora, ello implicará que los judíos de excepción, con tal de participar en la vida social europea, tendrán que ingresar en un juego de ambigüedades sociales, en el cual se caracterizarán por vivir en la tensión de ser y no ser como judío; oponiéndose y diferenciándose continuamente del grueso de la población judía; conformándose con las demandas que se les imponen; y, por ello, viviendo al vaivén de lo que la sociedad les fuese solicitando.

Esta exigencia de excepcionalidad por parte de la sociedad alemana se enmarca, de acuerdo con la autora, en los planteamientos de los pensadores promotores de la asimilación judía: Herder, Lessing y Mendelssohn, mencionados por la filósofa alemana en los textos La Ilustración y la cuestión judía y Los orígenes del totalitarismo. 
Arendt (2010a) explicará que el término judío culto de excepción tiene su origen en el nuevo humanismo, el que la pensadora, citando a Herder, señala:

“Que buscaba expresamente 'nuevos especimenes de la humanidad' con cuya relación podría llegar a conseguirse un ejemplo de posible intimidad con todos los tipos de humanidad (...) Fue Herder, un declarado amigo de los judíos, quien primero utilizó la frase posteriormente mal empleada y mal citada: 'Extraño pueblo de Asia conducido hacia nuestras regiones'. Con estas palabras, él y quienes eran como él saludaban a los 'nuevos especimenes de la humanidad', en cuya búsqueda el siglo XVIII había 'rastreado la Tierra', sólo para acabar encontrándolos en sus ancestrales vecinos" (p.131).

De esta cita se desprende que Herder, referido por Arendt, se encontraba resuelto en hallar la unidad básica de la humanidad, aquello que vinculara a todos los seres humanos entre sí. Por ello buscaba a estos 'nuevos especímenes de la humanidad' con los que poder relacionarse, para demostrar así el ejemplo a seguir de posible intimidad entre todos los tipos de hombres. Como señala la pensadora, Herder tenía un gran entusiasmo por encontrar nuevos pueblos de cualquier color, de países extraños y extranjeros, tenía un deseo de descubrir, probar y vincularse con cada 'nuevo espécimen', mostrando así el respeto por la idea de humanidad.

Si analizamos el término espécimen podemos observar cómo se define como aquellas muestras, modelos o ejemplares usualmente con las características de su especie muy bien definidas, con los cuales vincularse. Ello implicará que esta especie estará compuesta, a su vez, por individuos con caracteres en común, por los cuales se asemejarán entre sí, pero que los harán distinguirse de los demás. 
De esta forma, Herder, leído por la filósofa alemana, verá en los judíos a estos nuevos ejemplares buscados durante el siglo XVIII con los que poder intimar y a través de los cuales será posible descubrir nuevas facetas de la humanidad. Así, para el pensador, citado por Arendt, los judíos tendrán las características de su especie bien establecidas, igualándose y vinculándose entre sí, pero diferenciándose, por estos caracteres en común, del resto de los miembros de la sociedad.

Producto de esta separación establecida entre los judíos y la sociedad europea occidental, el filósofo alemán, de acuerdo con Arendt (2010a), se referirá de los judíos como un 'extraño pueblo de Asia conducido hacia nuestras regiones' (p.131); lo que se vinculará a su vez con las palabras citadas por el historiador Salo W. Baron (1960), quien explicaba que durante el período pre emancipatorio, “independiente del tiempo que los judios habitaran un país, o del hecho que en algunas partes sus antepasados se hubieran radicado mucho antes de la llegada de la mayoría cristiana (...) se los consideraba extranjeros que vivían allí transitoriamente, por mera tolerancia" (p.1).

Esta noción de extranjeridad, siguiendo a Baron (1960), puede ser entendida en primer lugar ya que tanto cristianos como judíos habían coincidido en que desde la destrucción del Segundo Templo de Jerusalén, los judíos radicaban en Europa como vecinos de cierta forma pasajeros, que serían devueltos, con el paso del tiempo, a su antiguo hogar en Palestina.

En este contexto, si conceptualizamos el término extranjero podemos apreciar cómo se define como el individuo que viene de un país que tiene otra soberanía o que es natural de otra nación. Entonces, podemos decir, que los miembros del pueblo judío eran vistos por la sociedad como un grupo que desde el inicio de la diáspora judía, provenía de otro lugar, de otro país o región. Y, al ser percibidos como extranjeros, se los consideraba con una residencia que podía ser transitoria, eran apreciados como vecinos temporales, pasajeros, que eventualmente volverían a su lugar de origen. 
En esta condición, los miembros de este pueblo en términos legales y políticos no contaban con la ciudadanía y no recibían el reconocimiento del Estado de sus derechos y deberes como ciudadanos. ${ }^{2}$

Ahora bien, si efectuamos un siguiente paso y analizamos la noción de diáspora, podemos observar cómo este concepto se define como la dispersión de los judíos exiliados de su país. Entonces, si bien los judíos eran percibidos como extranjeros, es decir, como individuos que provenían de otro país o nación y, por ello, como vecinos de cierta forma pasajeros; al vivir en una situación de diáspora, de exilio, no contaban con una tierra a la que poder volver, no tenían un lugar al que retornar tras su residencia temporal en Europa.

Este carácter transitorio de los judíos, hizo que se convirtieran en sujetos a los que se podía desarraigar si el país en el que radicaban ya no deseaba a los extranjeros que vivían allí transitoriamente. En otras palabras, lo judíos se transformaron en individuos a los que se podía expulsar o echar de un lugar, separándolos de los medios donde se habían criado y cortando por ello con los afectos que habían desarrollado en su entorno. De esta forma, los

${ }^{2}$ Como se explica en la Enciclopedia Judaica Castellana, la emancipación judía en Alemania llegaría en el siglo XIX. "Los judíos alemanes debieron su liberación, gradual por cierto y completa sólo durante algunos decenios, a la Revolución francesa, que vino a romper sus cadenas por dos caminos: Los ejércitos de la joven República y los de Napoleón al invadir el occidente del Reich (...) (Y) Por otra parte, las monarquías alemanas, derrotadas y trémulas ante el trueno de una tormenta popular que amenazaba derrumbar sus tronos, se apresuraron en introducir reformas liberales, aunque sólo en la medida necesaria para salvar el régimen (...) Con éstas cayeron también, temporalmente, los muros del ghetto (...) (Sin embargo) La caída de Napoleón sumió a Europa en una noche cultural y política, que debía durar más de treinta años (1815-1848). Los pueblos alemanes orgullosos de su santo entusiasmo patriótico, recibieron la merecida recompensa en el Congreso de Viena (1814-1815) (...) (entonces) se permitió revocar la igualdad legal de los judíos en todos los países alemanes, a excepción de Austria, Prusia y Baden, por haber sido impuesta o inspirada por los franceses (...) En 1819 estallaron en toda Alemania los tumultos antijudíos (...) en contra de una política favorable a los judíos (...) Hacia 1848, año de la Revolución de Marzo, los derechos de los judíos de Prusia quedaron reducidos a una fracción de lo que les había garantizado el edicto de 1812 (...) La gran revolución europea, el Marzo de las Naciones, llevó a la burguesía alemana al poder y proclamó los derechos del ciudadano, liberando así de golpe a los judíos (...) Pero la contrarrevolución no se hizo esperar. La Constitución prusiana (...) de 1850, redujo de nuevo los derechos de los judíos (...) A pesar de todo, la unificación de Alemania condujo, paulatinamente, a la completa emancipación judía (...) La Dieta del Norddeutsche Bund votó (...) en 1869 una ley, propuesta por el rey Guillermo I de Prusia y ratificada con la firma del Canciller Otto von Bismarck, que dice así: 'Todas las restricciones existentes en los derechos civiles y nacionales por motivos de diferencias de culto quedan abolidas' (...) A raíz de la guerra franco-alemana de 1870-1871, y de la fundación del Reich, la ley igualitaria aceptada por el Norddeutsche Bund se extendió a los Estados del sur (...) Hasta la caída del Segundo Reich en 1918, sin embargo, la política de los gobiernos alemanes distaba mucho de respetar religiosamente la ley fundamental de 1869, incorporada en la Constitución imperial (...) Fue el advenimiento de la República de Weimar (1919-1933) el que, por quince años, eliminó hasta los últimos vestigios de la desigualdad judía". (Weinfeld \& Babani, 1948, primer tomo, pp. 179-183) 
judíos envueltos en la transitoriedad que produce el exilio, pierden su arraigo, es decir, el poder de echar raíces, de establecerse de manera permanente en un lugar, vinculándose a personas y cosas.

Ahora bien, si volvemos a la lectura que Arendt realiza de Herder, la autora señalará que lo que estaba realizando el filósofo alemán era una invitación a los judíos a la vida europea; justamente a quienes habían habitado como extranjeros, viviendo de forma separada al resto de la sociedad, radicando como vecinos de cierta forma transitorios, que serían devueltos con el paso del tiempo a su antigua patria en Asia. Herder, leído por la pensadora, estaba dando la bienvenida a los judíos a establecerse en Alemania, a aquellos individuos que vivían carentes de arraigo.

Sin embargo, como explicará Arendt (2010a), para Herder sólo los judíos cultos, es decir, sólo los judíos que fuesen una excepción, podrían constituirse en estos nuevos especímenes de la humanidad.

"Protestando contra la costumbre de la época de otorgar 'concesiones de nuevos privilegios mercantiles', propuso la educación como verdadero camino para la emancipación de los judios del judaísmo, de 'los antiguos y orgullosos prejuicios nacionales..., de costumbres que no pertenecen a nuestra época ni a nuestras constituciones', para que los judios pudieran llegar a ser 'puramente humanizados' y útiles 'al desarrollo de las ciencias y a toda la cultura de la humanidad"' (p.131).

De esta cita se desprende, que para Herder, referido por Arendt, sólo el judío culto será quien podrá insertarse en la vida europea, pero sólo una vez que logre la desvinculación con el judaísmo, lo que para el pensador alemán, citado por la autora, era considerado como algo positivo, ya que ‘salvaría a los judíos del abismo' y los haría llegar a ser 'puramente humanizados', útiles 'al desarrollo de las ciencias' y a 'toda la cultura de la humanidad'. 
Siguiendo a la filósofa alemana, podemos plantear que Herder propondrá la educación de los judíos cultos como el verdadero camino para la emancipación del judaísmo. Es decir, sólo a través de la formación los judíos quedarán libres de sus antiguos 'prejuicios nacionales' y de las costumbres que los constituían y que no pertenecían a las circunstancias ni a las constituciones de la época. Como indica Arendt, en el texto La Ilustración y la cuestión judía:

"En el seno de una realidad histórica, en el seno del mundo europeo secularizado, se ven obligados a adaptarse de alguna manera a este mundo, a formarse. Sin embargo, para ellos la cultura es necesariamente todo aquello que está fuera del mundo judío. Como se les ha privado de su propio pasado, el presente empieza a mostrar su poder”. (Kohn \& Feldman editores, 2009, p.93)

Para comprender esta cita se hace necesario aproximarnos a la teoría de la Bildung o formación, clave en la idea de educación del idealismo romántico alemán. Será Herder uno de los pensadores iniciales en utilizar la concepción de la Bildung como formación cultural, en su libro Filosofía de la historia para la educación de la humanidad.

Herder será el primero en hablar de la formación como autoformación a través de la instrucción y la educación. Ello se convertirá luego en un tópico romántico, en el cual la formación y sus modelos serán lo más importante. En la Bildung que plantea el filósofo alemán, lo que prevalecerá será la idea de la forma cultural, los gestos de expresión, así por ejemplo, en la literatura surgirá la novela que ayuda al individuo a formarse a sí mismo (Bildungsroman).

Ahora bien, si llevamos el proceso de formación, de la Bildung que plantea Herder, a la noción del judío culto de excepción, podemos decir que, en cierto sentido, también habrían elementos de la asimilación judía que se juegan en este proceso. Finalmente, lo que 
solicitará el pensador, referido por Arendt, es que los judíos de excepción sean formados en los valores alemanes, desentendiéndose así de su propia formación cultural judía. Para los judíos que se deseen insertar en el mundo europeo, la cultura, necesariamente, será todo aquello que esté fuera del judaísmo, ya que se tratará de la formación en la cultura alemana. De esta forma, Arendt, al citar a Herder en la relación entre la Bildung romántica de la formación y el proceso de la inserción de los judíos cultos de excepción a la vida europea, estará mostrando cómo la Bildung puede ser la contracara de la exclusión. Que Herder postule, de acuerdo con la filósofa alemana, que sólo los judíos cultos serán 'puramente humanizados', es decir, invitados a asimilarse a la vida europea y a emanciparse del judaísmo para incorporarse a la sociedad occidental, implica una excepcionalidad excluyente.

En este punto, la pensadora nos presentará una nueva situación de exclusión en Herder, que se vuelve aún más feroz y que por ello adquiere un nuevo significado. Se tratará ahora de la exclusión del mismo judaísmo en aquellos judíos de excepción que son aceptados a la vida europea. Es decir, la excepcionalidad de esos judíos los deja integrarse a condición de que renieguen y renuncien a su propio judaísmo. Así, incluso los admitidos, son excluidos, en tanto se les hace renegar de lo más básico, de su condición de judíos. Se les hace ver como incompatible el ser aceptado en la sociedad europea con su condición judía.

De esta manera, como precisa la autora, se coloca a los judíos en un estado de excepción, que en la Ilustración que no tenía un sentido histórico muy desarrollado, todavía podía quedar oculto. Con Herder, considerado por Arendt como pensador romántico, crítico de la Ilustración, se les pide a los judíos que sean especiales y que, solo así, se los incluirá a la vida europea, en la cultura del género humano (Kohn \& Feldman editores, 2009). Ahora bien, Arendt indicará en relación al autor alemán que:

'Si sólo los judíos son personas 'cultas' en el sentido de Herder, la humanidad ha logrado recuperarlos (...) 'Vencidos los viejos prejuicios nacionales; abandonadas las costumbres que no encajan con nuestra época 
ni con nuestras circunstancias, ni siquiera con nuestro clima, los judíos ya no son esclavos (...) sino gente integrada en los pueblos cultos (...) que trabaja en la construcción de la ciencia, de la cultura del género humano (...) Para hacer de ellos personas honestas, no es necesario concederles ventajas en el ámbito comercial, son ellos mismos los que avanzan en esta dirección en virtud de sus méritos como seres humanos, como científicos y como ciudadanos. Allí donde viven y trabajan de forma honrada, allí está su Palestina". (Kohn \& Feldman editores, 2009, p.92)

De esta referencia se desprende, de acuerdo al análisis de Arendt, que Herder hablará de los judíos cultos, como aquellos que salen de la indigencia social o de la diáspora judía y dejan de ser 'esclavos'. Se trata de cambiar su 'Palestina' al presente, a un desempeño, es decir, a la actividad del trabajo, y ya no a un lugar físico. Por ello Arendt citará las palabras del pensador alemán 'allí donde viven y trabajan de forma honrada, allí está su Palestina'.

Sin embargo, si profundizamos en esta cita, podemos observar que no se tratará solamente de remplazar el lugar físico por el oficio como forma de trabajo. Sino que esta relación sustituye el vínculo con el hogar, con la nación. Se ofrece así un reemplazo al judío formado a su dependencia con la patria ancestral, a su arraigo con su tierra, que ahora es abstracta, para pasar a una relación autogenerada y organizada desde la acción del trabajo.

De esta manera, de acuerdo con la filósofa alemana, para el pensador alemán la actividad del trabajo en el caso de los judíos, vendría a sustituir a su nación, a su lugar en el mundo. Si analizamos el término trabajo, podemos observar cómo ciertas definiciones de esta palabra la relacionan con una ocupación que es retribuida; con una obra resultado de la actividad humana; con la operación de una máquina, pieza, herramienta o utensilio que se emplea para algún fin; o como el esfuerzo humano aplicado a la producción. 
Entonces, si empleamos estas definiciones al judío formado, podemos decir que lo que Herder, leído por Arendt, le estará pidiendo al judío culto de excepción es que se convierta en un ser humano ocupado e insertado en el mundo laboral alemán; que su esfuerzo esté aplicado a la producción, al comercio, la ciencia y la cultura. En otras palabras, que los judíos cultos sean entes productivos, mano de obra local insertados en la vida europea.

Más aún si consideramos que lo que siempre se le reconoció al judío culto de excepción desde la sociedad gentil, fue su capacidad extraordinaria, de vanguardia, para dominar la labor, tanto para el trabajo intelectual, industrial como para las profesiones liberales. Sobre todo, como señala la pensadora en el texto La cuestión judía, si tenemos en cuenta cómo la cuestión del trabajo durante este período tuvo relación con la incorporación de los judíos en las ramas de la economía burguesa en Alemania, incluso aunque la realidad fáctica de iguales derechos económicos no les hubiese otorgado la legitimación política o jurídica como ciudadanos (Kohn \& Feldman editores, 2009).

En este contexto, el pensador alemán, citado por Arendt, postulará que en tanto los judíos cultos se conviertan en individuos productivos en Alemania, dejarán de lado sus 'viejos prejuicios nacionales' (Kohn \& Feldman editores, 2009, p.92). En otras palabras, para Herder mediante el trabajo en esta nación europea, los judíos cultos de excepción se desvincularán de su nación ancestral y, con ello, de su condición de extranjeros y de su vida en diáspora, es decir, en el exilio del Estado Judío.

De esta forma, los judíos cultos de excepción al abandonar su aspiración nacional, se transformarán en mano de obra alemana, integrados 'en los pueblos cultos', que trabajan en la construcción de la cultura del género humano. Así, Herder, referido por Arendt, sustituirá Palestina, la antigua identidad nacional de los judíos, por Alemania, como la nación en la que desempeñarse laboralmente y como su verdadero hogar.

Será en este contexto, desde la perspectiva de la filósofa alemana, que Herder hará un llamado al judío formado a renunciar al sueño de la nación judía y hacer una asimilación 
completa en la sociedad europea occidental. Le pedirá al judío formado que, a cambio de la asimilación social, renuncie a lo más propio de su historia e identidad nacional.

\section{Abandono de la religión y su relación con la razón}

Como señala Arendt (2010a, p.132):

"Difícilmente puede sobrestimarse el desastroso efecto de esta exagerada buena voluntad hacia los judios cultos y recientemente occidentalizados y el impacto que tuvo en su posición social y psicológica. No sólo tuvieron que enfrentarse éstos con la desmoralizante exigencia de ser excepciones respecto de su propio pueblo, de reconocer 'la aguda diferencia entre ellos y los demás' (...) se esperaba de ellos, además, que se convirtieran en especímenes excepcionales de la humanidad. Y como esto (...) constituía la verdadera 'tarjeta de admisión' en la sociedad culta europea, ¿qué podían hacer esta generación y las futuras generaciones de judios sino tratar desesperadamente de no decepcionar a nadie?".

Pero de inmediato Arendt (2010a) nos aclara que esta cita no se puede aplicar a Mendelssohn, quien apenas conocía los pensamientos de Herder. Y nos dice que en el filósofo judeoalemán:

"Su firme adhesión a la religión judía le impidió romper en definitiva con el pueblo judio, lo que hicieron sus sucesores como cosa corriente. Sentía que era 'miembro de un pueblo oprimido que debía suplicar la buena voluntady la protección de la nación gobernante' (...) siempre supo que a la extraordinaria estimación por su persona correspondía un extraordinario 
desprecio por su pueblo. Como él, a diferencia de judíos de ulteriores generaciones, no compartía este desprecio, no se consideraba a sí mismo una excepción" (p.132).

Si analizamos esta cita podemos observar cómo para Arendt, Mendelssohn encarnará la figura de la fidelidad con la religión judía, lo que le impidió cortar los vínculos con su pueblo. Como precisa la autora en el texto La Ilustración y la cuestión judía, ello se debió a que la recepción de la Ilustración por parte de Mendelssohn, su "formación" (Kohn \& Feldman editores, 2009, p.82), su Bildung, aún tuvo lugar en el marco del judaísmo y su objetivo era defender este marco. Sin embargo, la pensadora planteará que Mendelssohn, además de hacer una apología al judaísmo, resguardará la posibilidad de su propia formación y, para ello, se servirá de la absoluta autonomía de la razón proclamada por la Ilustración.

En este sentido, para el filósofo judeoalemán, siguiendo a Arendt, la capacidad de pensar por sí mismo anunciada por Lessing (Selbstdenken, pensamiento independiente por uno mismo) constituirá la base del ideal de su formación. Para aclarar lo señalado, es necesario ingresar brevemente al pensamiento de Lessing, referido por la filósofa alemana en el texto Hombres en tiempos de oscuridad.

En primer lugar, como indica la pensadora, podemos decir que el Selbstdenken planteado por Lessing, no será una actividad que le pertenezca a un individuo cerrado en sí mismo, orgánicamente desarrollado y cultivado que observa a su alrededor para ver cuál es el lugar más favorable en el mundo para su desarrollo. Arendt (2008, p.18) planteará que el "pensamiento de sí mismo", se basará en que Lessing no vinculará su pensamiento con los resultados obtenidos, debido a que los resultados significarían la solución final a los problemas que su pensamiento planteaba para sí mismo.

De esta forma, Arendt (2008) nos indicará que el pensamiento, para el autor alemán, no estará en función de una búsqueda de la verdad, dado que cada verdad, que es el resultado 
de un proceso de pensamiento, pone necesariamente un punto final al movimiento del pensamiento. En este sentido, el pensamiento de Lessing, de acuerdo a la filósofa alemana, no será el silencioso diálogo platónico entre yo y yo mismo, sino que será un diálogo con los otros. Para el autor, así, no tendrá objeto comunicar conclusiones, sino que por el contrario, estimular a otros al pensamiento independiente, con el propósito de crear un discurso entre pensadores.

Ahora bien, volviendo a Mendelssohn, podemos decir que el filósofo judeoalemán dará un giro a la tesis que plantea Lessing sobre la separación entre las verdades de la razón y las verdades históricas. Como indica Arendt en La Ilustración y la cuestión judía, Mendelssohn transformará esta tesis en dogma y, basándose en ella, hará su defensa del judaísmo. Ello se traducirá en que para Mendelssohn, sólo la religión judía será idéntica a la racional, gracias a sus "verdades eternas" (Kohn \& Feldman editores, 2009, p.83), que son las únicas vinculantes desde un punto de vista religioso. Para el filósofo judeoalemán, siguiendo a la autora, las verdades históricas del judaísmo sólo fueron validas mientras la religión judía fue el credo de una nación, lo que no sucede desde la destrucción del Segundo Templo en Jerusalén. Por ello, para Mendelssohn, solo las 'verdades eternas', a las que siempre se ha tenido acceso, constituyen el fundamento de la religión judía y son las que comprometen a los judíos con el judaísmo.

Para el filósofo judeoalemán, siguiendo a Arendt, como en el Antiguo Testamento no hay nada que se oponga y sea contrario a la razón, el judío estará comprometido con unas leyes situadas más allá de la razón que, sin embargo, el no judío no tiene por qué acatar, ya que son ellas las que constituyen el elemento diferenciador entre los hombres y, por ello, son la base de la tolerancia. Para Mendelssohn, como explica la pensadora, la razón siempre ha sido igual de accesible para todos los hombres, en todas las épocas, lo único diferente es la vía de acceso a ella. La de los judíos no sólo implicará el acatamiento a la religión judía, sino que también la exacta observancia de la Ley en sí misma (Kohn \& Feldman editores, 2009). 
Como explica Arendt, en Lessing la distinción entre verdades históricas y verdades de la razón tenían como objetivo superar la dimensión dogmática de la religión. Sin embargo, como indica la autora, Mendelssohn se basará justamente en la dimensión dogmática de la religión para intentar salvar el judaísmo en base a su "contenido eterno" (Kohn \& Feldman editores, 2009, p.84), sus verdades eternas, independiente de su base histórica.

De esta forma, de acuerdo a lo indicado por la pensadora, el interés teológico del filósofo judeoalemán, que sería el responsable de la separación de la historia y la razón en el judaísmo, introduce, a su vez, la separación entre el hombre que busca la verdad, la revelación religiosa, versus el hombre que busca la historia. Como para Mendelssohn, de acuerdo con Arendt, la historia no tiene legitimización en la razón, el individuo que busca la historia en el judaísmo y fuera de él, carecería también de la validez de la razón.

Ahora bien, Mendelssohn además de defender el judaísmo en la Ilustración, será visto como una figura cultural trascendental de su época. Como señala Arendt (2010a, p.131) en Los orígenes del totalitarismo, se constituyó para los no judíos en:

"La prueba viva de que todos los hombres eran humanos. Para esta generación, la amistad con Mendelssohn (...) significaba una siempre renovada prueba de la dignidad del hombre. Y como los judios eran un pueblo despreciado y oprimido, constituían por eso un modelo aún más puro y más ejemplar de la humanidad".

Así, el filósofo judeoalemán se convertirá para los pensadores promotores de la asimilación judía, en la prueba viva, en una muestra excepcional, de que bastaría con que los judíos transformaran su posición social, para convertirlos en miembros social y culturalmente productivos a la sociedad; a pesar de que él 'no se consideraba a sí mismo una excepción' (Arendt, 2010a, p.132). 
De esta manera, Mendelssohn se convierte en el ejemplo vivo de lo que un judío culto, un judío de excepción, formado, podía significar en la vida europea. Era el modelo ejemplar de la 'dignidad del hombre', el modo más íntegro de humanización.

\section{Judío de excepción de la riqueza}

Como plantea Arendt (2010a) junto con el judío culto de excepción convivirá el "judío de excepción de la riqueza" (p.139), es decir, el judío palaciego y sus sucesores, los banqueros y los hombres de negocio de Occidente de origen judío. En primer lugar, la pensadora explicará que durante los siglos XVII y XVIII con el desarrollo de los Estados-Nación bajo la tutela de los monarcas absolutos, los individuos judíos que alcanzaron la posición de judíos palaciegos se caracterizaron por financiar las obras estatales y por realizar las transacciones financieras de sus príncipes. ${ }^{3}$

Más adelante, como plantea Arendt (2010a), tras la Revolución francesa y el surgimiento de los Estados-Nación en su sentido moderno, sus transacciones económicas requirieron de una mayor cantidad de capital y crédito, del que se les había pedido a los judíos palaciegos que pusieran a disposición de sus príncipes. De acuerdo con la autora, las riquezas de los más ricos estratos de la judería de Europa occidental y central, consignadas para estos fines a importantes banqueros judíos, atendieron las nuevas necesidades de los gobiernos.

Como plantea Arendt (2010a) a fines del siglo XVIII ninguno de los estamentos o clases de los diferentes países europeos deseaba o era capaz de convertirse en la nueva clase rectora, con tal de identificarse con el gobierno como lo había realizado la nobleza durante siglos. La filósofa alemana explicará que al no originarse un sustituto de la monarquía absoluta, se producirá el completo desarrollo del Estado-Nación y su reivindicación de hallarse por

${ }^{3}$ Como se señala en la Enciclopedia Judaica Castellana, los judíos de la corte surgieron principalmente en Alemania y Austria, desde fines de la Guerra de los Treinta años (1648) hasta el término del siglo XVIII. Nacieron "donde hábiles comerciantes y financieros (judíos) fueros encargados por reyes y príncipes de las transacciones económicas más importantes (...) Crearon nuevas empresas industriales y agrícolas, emprendieron misiones comerciales en el extranjero y prestaron ayuda financiera a los soberanos en momentos de apuro. Los judios de la corte tenían fácil acceso al soberano y les estaba permitido residir en cualquiera de las localidades donde no se permitía la estancia a otra clase de judíos (...) Estaban en situación privilegiada también en materia fiscal, ya que no se les podía gravar más que a los comerciantes cristianos y tenían permiso para hacer operaciones al por mayor y al por menor sin restricciones (...) pero también estaban expuestos a súbita ruina y hasta a perder la vida, cuando sus empresas fracasaban o cuando el país se hallaba en crisis económica debido a las guerras continuas". (Weinfeld \& Babani, 1948, Tercer Tomo, p.175) 
encima de todas las clases, y de ser independiente de la sociedad y sus intereses particulares, como el único representante de la nación en su conjunto. Ello determinó, asimismo, una mayor distancia entre el Estado y la sociedad sobre la que descansaba el cuerpo político.

De esta forma, Arendt (2010a) precisará que al fracasar los intentos del Estado de aliarse con una de las grandes clases de la sociedad, el Estado decidirá establecerse por sí mismo como un gran complejo empresarial, principalmente con fines administrativos, sumado a ello, a una gama de intereses financieros y de otro tipo, además de los costes generados. El crecimiento independiente de las actividades empresariales del Estado, como explica la pensadora, fue provocado por un conflicto con las fuerzas financieramente poderosas de la época, con la burguesía, la que optó por inversiones privadas, negándose a participar económicamente de forma activa de esta empresa estatal. Así, la filósofa alemana precisará que los judíos fueron la única parte de la población dispuesta a financiar los comienzos del Estado y a unir su destino a su posterior evolución. Arendt indicará que los judíos de excepción de la riqueza con su crédito y sus relaciones internacionales se hallaban en una posición privilegiada para ayudar al Estado-Nación a establecerse como una de las mayores empresas.

En este sentido, Arendt (2010a) destacará los privilegios obtenidos por los judíos de excepción de la riqueza por parte del Estado, como precio a pagar por el otorgamiento de estos servicios económicos y como premio por los riesgos corridos. "Este período trajo consigo la concesión de privilegios (por parte de los Estados-Nación), que hasta entonces sólo habían necesitado los judíos palaciegos, a una más amplia clase adinerada (de judíos), que habían conseguido instalarse durante el siglo XVIII en los más importantes centros urbanos y financieros" (p.79).

Siguiendo los planteamientos de la filósofa alemana, podemos observar de esta forma cómo a cambio de los servicios prestados por los judíos palaciegos y sus sucesores, el EstadoNación les dará privilegios, por la ayuda financiera proporcionada. Así, mediante la concesión de ventajas exclusivas, el Estado le otorgará a este grupo una condición de 
excepcionalidad, la que puede ser entendida como excluyente: se tratará de la aceptación y el otorgamiento de privilegios para unos pocos, los judíos de excepción de la riqueza; en virtud de la marginación de los muchos, el grueso de la población judía. Ahora bien, Arendt (2010a, p.137) precisará que:

"Los judios palaciegos y los ricos banqueros judios que siguieron sus huellas, jamás desearon abandonar la comunidad judía. Frente a las autoridades públicas actuaron como sus representantes y protectores; se les daba frecuentemente poder oficial sobre las comunidades que gobernaban desde lejos, de forma tal que la antigua autonomía de las comunidades judías resultó disminuía y destruida mucho antes de que fuera abolida por el Estado-Nación (...) la práctica de afirmar a los judíos palaciegos como dictadores de sus comunidades se generalizó en el siglo XVIII".

De esta referencia se infiere, en primer lugar, cómo los judíos de excepción de la riqueza a pesar de querer diferenciarse de la masa judía, con tal de obtener privilegios excepcionales, no abandonaron su comunidad judía de origen. Incluso, como señala la pensadora, los judíos palaciegos y los banqueros judíos, actuaron como sus representantes y protectores frente a las autoridades, y se les daba habitualmente poder oficial sobre las colectividades. Los judíos de excepción de la riqueza, se vuelven así, en los intermediarios de la comunidad judía con el Estado, adquiriendo por ello una gran influencia sobre el pueblo judío. Y, debido a su fácil acceso con las autoridades, las masas judías dependían constantemente de sus servicios para afrontar la vida en su colectividad. De esta forma, los judíos palaciegos y quienes siguieron sus huellas, obtuvieron una posición de poder y dominio sobre el pueblo judío.

Si definimos el término dominar, podemos observar cómo se relaciona con el tener dominio sobre alguien o algo, con sujetar, contener, reprimir o sobresalir entre otros. Y la palabra poder, por otra parte, se puede vincular con el dominio, imperio, facultad y jurisdicción que 
alguien tiene para mandar o ejercer algo; y, a su vez, con el acto o instrumento en que consta la facultad que alguien da a otra persona para que en lugar suyo y representándole pueda ejecutar algo.

En este sentido, podemos apreciar cómo el judío de excepción de la riqueza intentará dominar, contener o reprimir a su comunidad, en función de sobresalir frente a la masa judía empobrecida. Y contará para ello con la facultad otorgada por las autoridades, para que en lugar suyo, los represente. Contando, de esta manera, con la jurisdicción para mandar en su comunidad.

Asimismo, podemos analizar cómo esta permanencia en la comunidad de origen por parte del judío palaciego y sus sucesores, no estará solamente vinculada con el poder y la influencia. También puede ser entendida como una posibilidad de obtener arraigo. Es decir, será el judaísmo que le ofrece su colectividad, el espacio donde el judío de excepción de la riqueza sentirá que puede establecerse, que puede relacionarse con otras personas y elementos similares a él.

Por este motivo, como indica la filósofa alemana, el judío de excepción de la riqueza no saldrá de los límites de su comunidad y no buscará insertarse socialmente en la vida europea, ya que será su colectividad judía de origen la que le dará su posición de dominio y su sentido de pertenencia. ${ }^{4}$

\section{Conclusiones}

Como señalábamos inicialmente, si observamos los planteamientos efectuados por Arendt en los textos La Ilustración y la cuestión judía y Los orígenes del totalitarismo, podemos

\footnotetext{
${ }^{4}$ Cabe destacar que en relación a los servicios económicos prestados por los judíos de excepción de la riqueza, Arendt (2010a, p.80) precisará que "como esta íntima relación entre el gobierno nacional y los judíos había descansado sobre la indiferencia de la burguesía a la política en general y a la finanzas públicas en particular, este período concluyó con la aparición del imperialismo a fines del siglo XIX, cuando las actividades capitalistas en forma de expansión ya no podían ser realizadas sin la activa ayuda política y la intervención del Estado. El imperialismo, por otra parte, minó los auténticos cimientos del Estado-Nación e introdujo en el concierto de las naciones europeas el espíritu competitivo del mundo de los negocios. En las primeras décadas de esta evolución los judíos perdieron su posición exclusiva dentro de las finanzas públicas en beneficio de los empresarios de mentalidad imperialista; decayó su importancia como grupo (....) (y) necesitaban aún menos de la comunidad judía en general, no obstante su riqueza, que los judíos palaciegos de los siglos XVII y XVIII, y por eso frecuentemente se separaron por completo de la comunidad judía".
} 
indicar cómo la filósofa alemana distinguirá en las figuras del judío culto de excepción y del judío de excepción de la riqueza, a dos imágenes ideales, es decir, a dos tipos humanos que expresan dos modelos de judíos concretos, los que para la autora representan individuos de vanguardia del proceso de asimilación entre la cultura europea formal moderna y la cultura judía.

Sin embargo, si profundizamos en este análisis, podemos apreciar cómo la filósofa alemana utilizará estas dos figuras arquetípicas para efectuar un planteamiento crítico, al considerar que ambos modelos de judíos sostuvieron un carácter antipolítico como parte o complemento del desarrollo de su emancipación.

Para explicar este proceso, como indicábamos anteriormente, Arendt se situará en la Alemania del siglo XVIII, destacando a los pensadores promotores de la asimilación judía, Herder, Lessing y Mendelssohn y su conceptualización de la noción de judío culto de excepción. Si ingresamos en los planteamientos realizados por Herder, leídos por Arendt, podemos observar, cómo la propuesta de análisis efectuada por el filósofo alemán, tiende a elogiar las consecuencias que tendría para el judío culto la desvinculación con su judaísmo.

Para comprender lo señalado podemos señalar las palabras indicadas por la pensadora en el texto La Ilustración y la cuestión judía, en las cuales Herder efectuará su propia interpretación de la obra de Lessing, Nathan el Sabio:

"Lessing ha descubierto perfectamente esta falta de prejuicios de los judíos cultos, su forma más natural de ver las cosas; ¿y quién podría contradecirle, si ciertamente el judío está libre de muchos prejuicios políticos de los que a nosotros nos cuesta deshacernos o de los que no podemos deshacernos en absoluto?"”. (Kohn \& Feldman editores, 2009, p.92)

De esta cita se infiere, siguiendo a la filósofa alemana, que Herder en la interpretación que realiza de la obra de Lessing, pondrá de relieve la falta de prejuicios políticos de los judíos 
cultos de excepción. Para Herder, analizado por Arendt, este carácter desprejuiciado o de libertad del judío culto, puede ser entendido como una expresión positiva en relación a la ruptura de los vínculos del judío formado con el judaísmo, producto de la exigencia que la asimilación le impone. Es decir, el filósofo alemán, celebrará la desvinculación del judío culto de excepción con su pueblo de origen, alabando el desarraigo producido en el judío formado producto de su inserción a la vida europea.

Si definimos el término desarraigar, podemos observar cómo este concepto se relaciona con el arrancar de raíz una planta; con extinguir, extirpar enteramente una pasión, una costumbre o un vicio; con separar a alguien del lugar donde ha crecido, o con cortar los vínculos que se tiene con ellos. En este sentido, se puede plantear que Herder elogiará que los judíos cultos arranquen de raíz su judaísmo; que extingan cualquier pasión, costumbre o vicio que los relacione con su pueblo de origen; y celebrará que se separen del lugar donde se han criado, cortando todo lazo con la población judía, para asimilarse a la vida alemana.

Esta alabanza al desarraigo judío que efectúa el pensador, tiene sus antecedentes en la lectura que el autor realiza de los pueblos y la historia, en su libro Ideas para una filosofía de la historia de la humanidad. Para el filósofo alemán los pueblos tienen un momento en la historia y luego de ese instante mueren. Y, si no fallecen, viven de forma parasitaria, fuera de su época, no representando ya a la humanidad. En este sentido Herder (1959, p.379) indicará:

"El pueblo de Dios al que a su hora el mismo cielo donó una patria, hace miles de años, casi desde su origen es una planta parásita que vive sobre los troncos de otras naciones; un pueblo de astutos negociantes casi en toda la tierra, que a pesar de tanta opresión no aspira nunca al honor y a la propia morada y no conoce la nostalgia de la patria".

De esta referencia se desprende, que para el pensador el pueblo judío tuvo su momento en la historia, en tanto 'pueblo de Dios al que a su hora el mismo cielo donó una patria', 
espacio histórico que para el autor ya concluyó. En este contexto, señala Herder (1959, p.378): "la revolución que le tocó producir, probablemente ya se haya producido y para otra más no se encuentran indicios ni en el pueblo mismo ni en la analogía de la historia". Sin embargo, luego de la diáspora judía, este pueblo no desapareció y, al no fallecer, para el filósofo alemán, ha radicado esparcido como 'una planta parásita que vive sobre los troncos de otras naciones', sin aspirar 'a la propia morada'.

El término parásito se define como un organismo que vive a costa de otro de distinta especie, alimentándose de él y depauperándolo sin llegar a matarlo; o asimismo como una persona que vive a costa ajena. Así, podemos observar cómo para Herder el pueblo judío desde su vivencia en el exilio, donde se ha esparcido 'casi en toda la tierra', ha vivido de forma parasitaria, es decir, de acuerdo al autor, como un organismo diferenciado del resto, que vive y se nutre a costa ajena, a costa de otras naciones diferentes de la suya.

Ello se relacionará a su vez, como señalábamos anteriormente siguiendo los planteamientos de Arendt, con que para el filósofo alemán los judíos eran percibidos como extranjeros que radicaban de forma separada al resto de la sociedad, como vecinos de cierta forma transitorios. Sin embargo, esta percepción convivía con el problema real del pueblo judío,

\footnotetext{
${ }^{5}$ Cabe destacar que en el texto Antisemitismo, Arendt conceptualizará el término parásito vinculado a ciertos prejuicios relacionados con el antisemitismo. "Procedentes de prejuicios más o menos antisemitas, todas las definiciones modernas de los judíos como pueblo - con la única excepción de la definición por la raza- tienen su base histórica en condiciones medievales y tardomedievales. Los judíos como parásitos, como nación de parias, como casta, todo eso, con la excepción de unos pocos (aunque cruciales) residuos, se eliminó económicamente en el curso de los siglos XVIII y XIX, mientras que, al mismo tiempo, por medio de un tipo de contramovimientos políticos (antisemitas), los judíos fueron redefinidos, en realidad, como una casta de parias y parásitos. Los parásitos eran los usureros judíos: parásitos de la desintegración y de la destrucción del orden feudal. Las necesidades a las que asistían surgían de un mundo moribundo que les asignó el papel fatídico de proporcionar capital usurario, que servía para el consumo pero que tenía solamente una influencia destructiva en la producción". (Kohn \& Feldman editores, 2009, p.152)

Dada esta referencia planteada por la filósofa alemana, podemos indicar que el tratamiento de integración que parece tener Herder, de acuerdo con Arendt, también tendría un aspecto un tanto ambiguo, ya que posee elementos de una tradición que contiene ciertos prejuicios relacionados con el antisemitismo, que él asume. De esta manera podemos observar cómo la asimilación de los judíos a la sociedad alemana planteada por Herder, se relaciona no solamente con la integración, sino que también con la discriminación y la marginación, tratándose de un proceso cultural complejo -culturalmente, no se debería hablar de un pueblo al que se desea integrar del todo, como un pueblo parásito-. Así, Herder puede haber pensado en la asimilación de los judíos, sin embargo, en sus planteamientos, se le salen ciertos prejuicios, escalas de valores y jerarquías, donde hay pueblos que son la expresión del espíritu y otros que quedan en una situación de marginalidad; por ello, todas estas visiones, hacen que este proceso no vaya en una sola dirección. Es decir, este paso que puede haber dado Herder en la incorporación de los judíos a la vida europea, supone a su vez, reforzar una serie de prejuicios.
} 
el que vivía en una situación de exilio, en el que no contaba con una tierra a la que poder volver. De esta manera, la extranjeridad de los judíos en Europa se transformaría en una condición permanente, al estar carentes de un lugar físico al que poder retornar.

En esta condición, como indicábamos inicialmente, los miembros de este pueblo en términos legales y políticos no contaban con la ciudadanía y no recibían el reconocimiento del Estado de sus derechos y deberes como ciudadanos.

Será en este contexto que Herder invitará a los judíos formados en la cultura y valores alemanes a la vida europea, excluyendo de este proceso a las masas judías. Sin embargo, les solicitará a los judíos cultos renegar de su propia condición de judíos, como precio a pagar por la inserción a la sociedad. El autor les pedirá asimismo que se conviertan en seres humanos útiles a la fuerza productiva alemana, con tal de desvincularse de su nación ancestral, lo que para el pensador corresponde a una historia pasada que los judíos intentan aferrar y conservar al presente.

Mediante este análisis, podemos apreciar cómo Herder, desde la mirada de Arendt, le ofrecerá al judío culto de excepción una nueva situación de desarraigo. Es decir, el pensador le propondrá al judío formado sustituir el antiguo desarraigo producido por la diáspora judía, que de acuerdo al autor, lo había convertido en miembro de un pueblo considerado como extranjero y parasitario; por un nuevo desarraigo que considera como positivo: la desvinculación del judío culto del judaísmo.

Este desarraigo que Herder elogiará, implicará un gran costo cultural para los judíos formados. Para el pensador se tratará de arrancar a los judíos cultos de la 'planta parásita' que para él es este pueblo extranjero, para ser trasplantados rápidamente a otra cultura considerada como la predominante. De esta manera, este escenario pondría a los judíos cultos de excepción, talentosos, sensibles y adaptables, en una posición privilegiada para lo nuevo, lo específicamente moderno y europeo. 
Sin embargo, este contexto vuelve a producir una situación de exclusión. Los judíos cultos tendrán que instruirse en la cultura alemana, considerada como moderna y actual, renunciando a su propia identidad cultural, vista como tradicional. De esta forma, para los judíos formados, ya no será el pueblo judío el portador de sentido que todos comparten. Se tratará ahora del desarrollo de cada uno como individuo. Desarrollo que para Herder, de acuerdo con Arendt, estará en la formación del individuo (Bildung) de excepción en los valores de sociedad alemana, y ya no en la instrucción de los judíos en el judaísmo.

De esta forma, este traspaso cultural que Herder celebrará convertirá a estos individuos en seres carentes de raíces en la historia europea occidental, en sujetos que ya no tienen nada específico en lo que arraigarse, lo que para Herder posibilitará que puedan ser la expresión de la humanidad, ya que no poseerían nada en particular.

Así la desvinculación del judaísmo que Herder celebrará, implicará que los judíos cultos tengan que vivir envueltos no sólo en el vacío de su identidad cultural, sino que también en el vacío político. Los judíos formados al vivir faltos de su especificidad, del contenido que los origina y de su solidez, quedarán, a su vez, carentes de la historia y de la realidad que los rodea y, debido a ello, 'libres de muchos prejuicios políticos' (Kohn \& Feldman editores, 2009, p.92), es decir, faltos de prejuicios y contenidos, ya sea de su entorno, hechos o congéneres.

En este sentido, esta ceguera política se puede relacionar también con la definición del término vacío cuando se lo vincula con la palabra abismo o con el encontrarse al borde de una altura considerable. Entonces, si el judío formado vive en el vacío identitario y político, estará habitando, a su vez, en el extremo u orilla de un abismo o precipicio, al borde de una altura desde la cual podría caer a pique, al no saber o no querer observar el mundo que lo rodea políticamente, lo que sucede a su alrededor, su contexto, peligros, posibilidades y consecuencias.

Ahora bien, cuando la autora se refiere a la figura del judío culto de excepción, como señalábamos inicialmente, también destacará al filósofo judeoalemán Moses Mendelssohn, 
quien será visto por la sociedad de la época, como una figura trascendental. Como indica la pensadora, Mendelssohn se convertirá en el ejemplo vivo de lo que un judío formado podría significar en la vida europea, en el modelo más integro de humanización. En este contexto, Arendt (2010a, p.133) planteará que en:

"El Berlín ilustrado, donde Mendelssohn había establecido relaciones estrechas con muchos hombres famosos de su tiempo, era sólo un comienzo. Sus conexiones con la sociedad no judía todavía tenían mucho en común con los lazos culturales que habían ligado a sabios judios y cristianos en casi todos los periodos de la historia europea. El elemento nuevo y sorprendente consistía en el hecho de que los amigos de Mendelssohn emplearan estas relaciones para objetivos personales o ideológicos o incluso para fines políticos. Él mismo desaprobó explícitamente tales motivaciones ulteriores y expresó una vez y otra su clara satisfacción con las condiciones en las que tenía que vivir, como si hubiera previsto que su estatus social y su libertad, excepcionales, tenían algo que ver con el hecho de que todavía pertenecía al grupo de 'los habitantes de menor rango del dominio' (del rey de Prusia)".

De esta cita se desprende, cómo a pesar de las estrechas relaciones que Mendelssohn tuvo con los hombres más famosos y cultos de su tiempo, él mismo desaprobó que sus conocidos emplearan estos vínculos para objetivos ideológicos o políticos. Como señala Arendt (2010a), esta indiferencia del filósofo judeoalemán hacia las motivaciones políticas se aprecia, por ejemplo, en que mientras su amigo Lessing describía Prusia como "el más esclavizado país de Europa" (p.133), donde era imposible actuar y alzar "la voz por los derechos de los súbditos... contra la extorsión y el despotismo" (p.133). Mendelssohn 
expresaba su satisfacción con las condiciones en las que vivía, a pesar de estar entre 'los habitantes de menor rango del dominio' del rey de Prusia.

Para Arendt (2010a), la ceguera política de Mendelssohn sorprende más aún si se tiene en cuenta que el gobernante de Prusia había hecho sumamente difícil que el filósofo judeoalemán obtuviera permiso de estancia en Berlín. Mendelssohn, como explica la autora, era incluso consciente de que él, el amigo de toda la Alemania culta, estaría sujeto al mismo gravamen impuesto a un buey que se lleva al mercado, si quisiera visitar a su amigo Lavater en Leipzig, pero, como explica la pensadora, no se le ocurrió ninguna conclusión política relativa al mejoramiento de estas condiciones.

De esta forma, podemos apreciar como la capacidad que tuvo el filósofo judeoalemán para formarse, para hacer de sí mismo un hombre culto, lo que para Mendelssohn representaba su propia libertad, supuso a su vez las limitaciones de no ser realmente aceptado en la nación alemana. Así, el filósofo judeoalemán vivirá, al igual que el resto del pueblo judío, en una situación de extranjeridad, en una condición de marginalidad, teniendo penurias y restricciones como el grueso de la población judía.

Ahora bien, cabe destacar, como señalábamos anteriormente, que junto con el judío culto de excepción convivirá el judío de excepción de la riqueza, el judío palaciego y sus sucesores, los banqueros y los hombres de negocio de Occidente de origen judío. Como explica Arendt (2010a, p.83):

"En época tan temprana como el siglo XVIII, allí donde grupos enteros de judíos se enriquecían lo suficiente como para resultar útiles al Estado, disfrutaron de privilegios colectivos e, incluso en el mismo país, se separaron como grupo de sus hermanos menos ricos y útiles. Como los 
Schutzjuden ${ }^{6}$ de Prusia, los judios de Burdeos y de Bayona, en Francia, disfrutaron de la igualdad mucho antes de la Revolución Francesa".

De esta referencia se infiere que no sólo el Estado hará una diferenciación entre los judíos de excepción de la riqueza y el resto de la masa judía empobrecida. Sino que los propios judíos palaciegos y quienes siguieron sus huellas, se separarán de 'sus hermanos menos ricos y útiles'. Los judíos de excepción de la riqueza consientes, como indica Arendt (2010a, p.83), de "la naturaleza y de la condición de su estatus", considerarán que los privilegios obtenidos les era concedidos como recompensa a sus servicios económicos y, por ello, veían que "difícilmente podría llegar a ser un derecho para todos"(p.83). En virtud de mantener su posición de excepcionalidad y obtener ventajas exclusivas por parte del Estado, se separarán y diferenciarán del grueso de la población judía.

De esta forma, como señala Arendt, se puede observar como en este período donde los judíos no gozaban de la ciudadanía, los judíos de excepción de la riqueza disfrutaron en la forma de privilegio la igualdad. Sin embargo, ello se realizó en virtud de la marginación del pueblo judío, quienes debieron esperar hasta la emancipación para obtener este derecho. Así, como indica la pensadora, se puede apreciar cómo los judíos de excepción de la riqueza pensaban en términos de libertades excepcionales, pero no en ampliar estas ventajas a la masa judía o cambiar la situación política del pueblo judío en su conjunto.

Entonces, siguiendo el análisis realizado, podemos observar el diagnóstico que desarrolla la pensadora sobre las dos figuras expuestas: Arendt nos mostrará la falta de sentido político que sostuvieron en este período tanto el judío culto de excepción como el judío de excepción de la riqueza. Si bien para la filósofa alemana ambas figuras trabajarán el conflicto cultural, entre una cultura de origen y otra de acogida, ninguna de las dos se involucrará en otorgar una visión política a este proceso. En este sentido, Arendt no se referirá a la búsqueda del sentido de estos sujetos como individuos, como pueblo o dentro de la religión. Sino que lo que nos quiere decir es que ni el judío formado, ni el judío

\footnotetext{
${ }^{6}$ Judíos protegidos.
} 
palaciego y sus sucesores, lograron sacar un rendimiento político para la identidad judía y su comunidad, manteniendo una actitud antipolítica en Europa.

En este contexto, Arendt (2010a) señalará que el rol desempeñado por los judíos de excepción de la riqueza podría haber quedado en el olvido de la historia social, de no ser porque compartían ciertos rasgos psicológicos y normas de conducta con los judíos cultos de excepción. Finalmente, como precisa la autora, los judíos formados solían ser hijos de los hombres de negocio.

Como señala Arendt (2010a, p.139), "ambos compartirán el sentimiento de ser excepciones, un sentimiento que estaba en perfecta armonía con el juicio de su entorno"; ambos tenían en común el querer diferenciarse del grueso de la población judía. Así, como precisa la filósofa alemana, mientras los judíos de excepción de la riqueza se consideraban como excepciones al destino común del pueblo judío; los judíos de excepción de la cultura se veían a sí mismos como excepciones de la masa judía.

No obstante lo anterior, a pesar de que ambos tipos de judíos compartieran sentimientos de excepcionalidad en relación al pueblo judío; está excepcionalidad estará diferenciada en el reconocimiento que cada arquetipo judío tuvo de la sociedad europea y de su propia comunidad. De esta forma, siguiendo los planteamientos de Arendt (2010a, p.139), mientras que el judío de excepción de la riqueza "quería dominar al pueblo judío y por eso no deseaba abandonarlo", el judío de la cultura se caracterizaba justamente por desear abandonar su colectividad de origen, para poder asimilarse a la vida europea.

Asimismo, como indica la autora, mientras que los judíos palaciegos y sus sucesores, se preocuparán por mantener los vínculos económicos con el Estado-Nación y serán reconocidos como excepcionalmente útiles por los gobiernos; los judíos cultos se considerarán a sí mismos como seres humanos excepcionales y serán reconocidos de esta manera por la sociedad europea. 
Ahora bien, en relación a la práctica del judaísmo de los judíos de excepción, Arendt (2010a, p.141) nos dirá que:

"Las normas de conducta de los judíos asimilados, determinadas por este continuo y concentrado esfuerzo por distinguirse de los demás, crearon un tipo de judío que es reconocible en todas partes. En lugar de ser definidos por la nacionalidad o por la religión, los judíos se trasformaron en un grupo social cuyos miembros compartían ciertos atributos y reacciones psicológicas, la suma total de las cuales se suponía constitutiva de la 'judeidad'. En otras palabras, el judaísmo se convirtió en una cualidad psicológica y la cuestión judía en un problema personal para cada individuo judío".

Pero, ¿qué implicará que el judío formado no esté 'definido por la nacionalidad o por la religión'? Para responder esta pregunta podemos recurrir a la figura de Moses Mendelssohn y sus discípulos. En este sentido, la autora precisará que mientras que para el filósofo judeoalemán, 'su firme adhesión a la religión judía le impidió romper en definitiva con el pueblo judío', sus sucesores quebraron este vínculo como una cosa corriente. Ello se apreciará ya en la segunda generación de judíos asimilados (los discípulos de Mendelssohn), quienes romperán los vínculos con la religión y tratarán por todos los medios de hacerse un espacio en la sociedad. Como plantea la filósofa alemana, ellos se identificarán hasta tal punto con la obcecación de la Ilustración, para la cual los judíos no son más que individuos oprimidos, que renunciarán a su propia historia y considerarán que todo lo suyo no es más que un obstáculo para su integración a la sociedad. (Kohn \& Feldman editores, 2009)

De este planteamiento se deduce que desde la generación siguiente a la de Mendelssohn, los judíos cultos de excepción, a diferencia del filósofo judeoalemán, no podrán vivir 
insertos en su comunidad de origen para ser un real aporte a la sociedad. En ellos se comenzará a producir una ruptura en su identidad.

En este sentido, si pensamos en el judío de excepción de la riqueza, como señalábamos anteriormente, ellos nunca fueron socialmente aceptables ni abandonaron su comunidad de origen. Se podría considerar que esta situación se produjo ya que al judío palaciego y quienes siguieron sus huellas, no les interesaba asimilarse, ya que finalmente lo que 'quería (era) dominar al pueblo judío y por eso no deseaban abandonarlo' (Arendt, 2010a, p.139), además de conservar sus privilegios en base a su utilidad económica.

Sin embargo, también podría pensarse que el judío de excepción de la riqueza podría tener otras pretensiones. Como indicábamos inicialmente, siguiendo los planteamientos de Arendt, los judíos formados solían ser hijos de los hombres de negocios y, por ello, compartían ciertos rasgos psicológicos y normas de conducta. Y quizás no sea tan azaroso que los hijos de los judíos de excepción de la riqueza, fueran judíos cultos. Se podría considerar que los intelectuales judíos observaron la inserción incompleta que vivieron sus padres o las generaciones anteriores, condicionada a los servicios económicos prestados al Estado-Nación, donde a pesar de su aporte y los privilegios obtenidos, seguían siendo vistos como judíos. Tal vez por ello los judíos cultos de excepción intentaron cambiar esta situación adversa, tratando de convertirse en la vanguardia, en quienes dominan la lengua y dan los pasos decisivos en la cultura alemana, con tal de obtener una asimilación mayor a la que tuvieron sus progenitores.

Ahora bien, si reflexionamos en lo que compartían ambas figuras de excepción, podemos observar cómo en ambos modelos arquetípicos se produjo una tensión entre judaísmo y judeidad. Para profundizar en este análisis, podemos recurrir a la definición efectuada por el traductor del libro Hannah Arendt. Escritos judíos:

“Traduzco el vocablo 'Jewishness 'como 'judaicidad' (judeidad) o, también en algunos casos, como 'condición judia', a fin de distinguirlo de 'Judaism', que traduzco como 'judaísmo'. La razón de hacerlo así es que existe una 
notable diferencia entre ambos términos. El primero de ellos (Jewishness) señala el simple hecho de 'ser judio', como condición existencial del individuo, un factum que condiciona su existencia y que, como tal, no puede ser negado, si bien constituye una 'dotación meramente pasiva del ser' (del individuo).El segundo (Judaism) hace referencia a la religión, la tradición y la cultura judía, es decir, a las creencias, la historia y las costumbres de los judíos en cuanto pueblo”. (Kohn \& Feldman editores, 2009, p.16)

De este planteamiento se deduce que tanto el judío culto de excepción como el judío de excepción de la riqueza, no podrán vivir insertos sólo en su comunidad de origen para ser un real aporte a la sociedad. Como señalábamos anteriormente, en ellos, producto del proceso de asimilación a la vida alemana, se comenzará a producir una ruptura en su identidad, donde su judaísmo, entendido como 'la religión, la tradición y la cultura judía, es decir, las creencias, la historia y las costumbres de los judíos en cuanto pueblo', empezará a quebrase para llegar a convertirse en judeidad, es decir, en 'ciertos atributos y reacciones psicológicas', en una 'condición existencial del individuo', en 'un factum que condiciona su existencia' y que no puede ser negado, 'si bien constituye una dotación meramente pasiva del ser'(Kohn \& Feldman editores, 2009, p.16).

Para comprender lo señalado, primero debemos profundizar en el concepto de judeidad indicado por la pensadora alemana. Para ello nos podemos basar en los planteamientos efectuados por Fina Birulés en la Introducción al libro Hannah Arendt. Una revisión de la historia judía y otros ensayos. La filósofa española indicará que cuando Arendt (2005a) se refiere a la judeidad como 'el simple hecho de ser judío', como una 'dotación meramente pasiva del ser del individuo', como un "dato incontrovertible" (p.13), estará señalando todo aquello que no se ha elegido, donde no ha intervenido la iniciativa. Es decir, como explica Arendt en su Carta a Gershom Scholem, todo aquello que "es dado y no hemos hecho, ni puede ser hecho". (Kohn \& Feldman editores, 2009, p.570) 
Para comprender la cita indicada, Birulés explica que nadie escoge nacer hombre o mujer, judía o no judía. Como señala la pensadora española, todo individuo al nacer recibe algo de contingente y no elegido, algo que 'es dado y no hemos hecho, ni puede ser hecho'. De esta forma, Birulés dirá que cuando Arendt (2005a) reflexiona sobre la judeidad como lo que 'es dado', no lo realizará para indicar un tipo específico de personas, sino que se referirá aun "presente político" (p.13), a una cierta configuración del mundo que no tiene relación con una determinación natural o biológica, ya que toda vida, indica la pensadora española, surge en un momento concreto y en un tiempo específico, en el entorno de una comunidad y con unas características físicas o psicológicas particulares. En este sentido, Birulés agregará que:

"Este comienzo no es voluntario, no elegimos nacer en una época o en un cuerpo, cuyas características pueden ser valoradas positiva o negativamente; nacer es entrar a formar parte de un mundo de relaciones, de discursos y de normas que no hemos decidido y que, en cierta medida, nos constituyen. Lo que nos viene dado no es, sin embargo, una realidad neutra, sino que se presenta como un despliegue de diferencias -judía, mujer, etc.- que se entrecruzan en cada uno de nosotros. No obstante, esto dado, que se nos impone, no confiere, por sí mismo, ningún tipo de singularidad". (Arendt, 2005a, p.13)

Dada la referencia señalada, la filósofa española explicará que para Arendt el pensar y actuar a partir de la condición judía, de la judeidad, no se traducirá en que aquello configure una visión del mundo. Birulés indicará que para Arendt (2005a, p.13) lo que caracteriza a las personas es su capacidad de juzgar "y el primer mandato, al que siempre se mantendrá fiel, es el de 'pensar por sí misma' (Selbstdenken de Lessing)". 
Ello implicará, siguiendo a Birulés, que ejercemos el juicio sobre el fondo de un contexto concreto, de una coyuntura específica, por ello "pensar por sí mismo no es pensar a partir de nada, sino tomar posición, responder de y a lo que nos ha sido dado" (Arendt, 2005a, p.13). De esta forma, la pensadora española explicará que lo que nos ha sido otorgado no determinará nuestra visión del mundo y, por ello, frente a lo dado, se tomará una posición. Entonces, existen diversas respuestas posibles sobre lo que nos ha sido dado. Una de ellas es la que Arendt conceptualizará a través de la figura del judío de excepción, quien frente a lo que le ha sido otorgado, su judaísmo, tomará una posición en forma de tensión, de conflicto, de quiebre en su identidad, al salir de su comunidad judía de origen e intentar insertarse, cultural o económicamente, a la vida alemana.

De esta manera podemos observar, siguiendo los planteamientos de la pensadora, cómo esta condición de excepcionalidad dada por la cultura o la riqueza, implicará una manera incompleta de asimilación a la vida alemana y una respuesta insatisfactoria frente a aquello que nos 'es dado'.

Para comprender lo señalado, podemos precisar que el término tensión significa el estado de un cuerpo sometido a la acción de fuerzas opuestas que lo atraen; el estado de oposición u hostilidad latente entre personas o grupos humanos; y el estado anímico de excitación, impaciencia, esfuerzo o exaltación. A su vez, la palabra conflicto se entiende como el combate, la lucha o la pelea; como un apuro o una situación desgraciada y de difícil salida; y como la coexistencia de tendencias contradictorias en el individuo, capaces de generarle angustia y trastornos neuróticos.

Así, podemos apreciar cómo esta condición de excepcionalidad en la que viven envueltos los judíos de excepción, implicará que ambos arquetipos deberán vivir en un estado de tensión constante, es decir, sometidos a la acción de fuerzas opuestas que lo atraen -lo judío y lo europeo-; en un estado de oposición continuo entre personas o grupos humanos, al estar en un continuo y concentrado esfuerzo por distinguirse de los demás, por adaptarse a la sociedad alemana a través de la diferenciación y la distinción. Y, asimismo, se 
encontrarán en un estado anímico de excitación o impaciencia con tal de lograr la inserción social o la utilidad económica en Alemania.

Debido a lo anterior, el judío de excepción vivirá en conflicto consigo mismo, es decir, en una constante lucha o pelea interna, producida por la coexistencia de tendencias contradictorias que conviven en él, que le pueden generar angustia, es decir, aflicción, congoja, ansiedad, temor o incluso dolor o sufrimiento; al tener que diferenciarse claramente del "judío general" y, al mismo tiempo, demostrar que es judío, ya "que bajo ninguna circunstancia se les permitiría desaparecer entre sus vecinos". (Arendt, 2010a, p.141).

De esta forma, este estado de incertidumbre y hostilidad que rodea a la excepcionalidad, se relacionará a su vez con la ausencia de una perspectiva política del judío de excepción. Así podemos observar la trampa que implicará para ambos tipos de judíos el vivir envueltos en esta condición. De esta manera, el judío de excepción de la riqueza, se insertará en un mundo económico, donde el Estado le ofrecerá posibilidades privilegiadas, pero a su vez le dará desigualdad, ya que si bien le proporcionará un estatus superior en relación a la masa judía, dándole incluso poder oficial sobre ésta, este estatus privilegiado estará condicionado a su utilidad económica, por lo que no le otorgará una inserción real a la esfera pública.

Asimismo, a los judíos cultos de excepción se les ofrecerá una formación en los valores y cultura predominante, y se les dará la posibilidad de ser un aporte cultural y social. Sin embargo ésta será una visión utilitaria y marginal, ya que los judíos formados seguirán siendo percibidos como extranjeros, compartiendo condiciones políticas restringidas como el grueso de la población judía, no contarán con la ciudadanía ni un espacio a la luz del espacio público, siendo el ejemplo más claro el de Moses Mendelssohn.

De esta forma, ambas figuras envueltas en el sentimiento de excepcionalidad, perderán de vista, desde hace siglos, su despertar político, el estar preocupados de contar como judíos con una comunidad política; con construir algo sólido en la esfera pública europea desde su 
identidad; y con tener un territorio propio en el que los judíos tengan sus raíces y desde el cual puedan orientarse en el mundo.

\section{Bibliografía}

Arendt, H. (2005a). Una revisión de la historia judía y otros ensayos. Buenos Aires: Paidós.

Arendt, H. (2005b). Ensayos de comprensión 1930-1954. Madrid: Caparrós Editores.

Arendt, H. (2008). Hombres en tiempos de oscuridad (2 ${ }^{\mathrm{a}}$ Ed.). Barcelona: Gedisa.

Arendt, H. (2010a). Los orígenes del totalitarismo (4ª Ed.). Madrid: Alianza.

Arendt, H. (2010b). La condición humana (6 $6^{\mathrm{a}}$ Ed.). Buenos Aires: Paidós.

Baron, S. (1960). Nuevos enfoques acerca de la emancipación judía. Diógenes, vol. 29, 5681.

Herder, J. (1950). Filosofía de la historia para la educación de la humanidad. Buenos Aires: Nova.

Herder, J. (1959). Ideas para una filosofía de la historia de la humanidad. Buenos Aires: Losada.

Kohn, J. \& Feldman, R. (Ed.). (2009). Hannah Arendt. Escritos judíos. Madrid: Paidós.

Weinfeld, E. \& Babani, I. (1948). Enciclopedia Judaica Castellana (Vol.1, pp.157-198)

(Vol.2, pp. 68-71) (Vol.3, pp. 175-176) (Vol.4, pp. 85-90) (Vol.5pp. 284-287) (Vol.9, pp. 563-570). México: Editorial Enciclopedia Judaica Castellana, S. de R. L. 